\title{
Effects of pectolase concentration and yeast strains on carambola wine quality in Trinidad, West Indies
}

Vidya BRIDGeBASSIE, Neela BADRIE*

Department of Food Production, Faculty of Agriculture and Natural Sciences, The University of the West Indies, St. Augustine, Trinidad and Tobago, West Indies

nbadrie@yahoo.com badrie@carib-link.net
${ }^{*}$ Correspondence and reprints

Fruits, 2004, vol. 59, p. 131-140 (C) 2004 Cirad/EDP Sciences All rights reserved DOI: $10.1051 /$ fruits:2004013

RESUMEN EsPañol, p. 140

\section{Effects of different pectolase concentration and yeast strains on carambola wine quality in Trinidad, West Indies.}

Abstract - Introduction. The fruit of Averrhoa carambola L., or carambola, is an attractive tropical fruit of the Oxalidaceae family. As most of the carambola crop is consumed fresh, very few carambolas are processed. However, the high variability in fruit quality produced by Caribbean countries is a major limitation to market penetration. Processing of carambolas could allow the utilization of low quality fruits, which cannot be marketed, to reduce waste, improve on the economic returns of farmers and increase the value of the crop. Our work thus aimed at studying carambola wine quality in relation to certain treatments applied before the fermentation of the must. Materials and methods. Pectolase was added to the pasteurized carambola pulp to the concentrations of $(0,0.1,0.2$ and 0.3$) \%$. Another treatment used pectolase to $0.3 \%$ with addition of $1 \%$ of citric acid and $0.25 \%$ of ascorbic acid and associated with the use of various yeast strains of Saccharomyces cerevisiae from various wines (Super, Chablis and Sweet Mead). The must was adjusted to $25^{\circ}$ Brix and $\mathrm{pH} 3.0-3.5$. The carambola wine quality obtained at the end of each treatment was assessed using physicochemical characteristics and sensory evaluations. Results and discussion. Addition of pectolase improved the carambola wine's light transmittance, sensory color, sensory clarity and overall acceptability. Addition of 1\% citric acid and $0.25 \%$ ascorbic acid to the must resulted in less dark and yellow wines with a more acceptable color. Wines fermented with the Chablis yeast strain had the highest clarity $(88.55 \%$ of light transmittance). The wines were microbiologically stable. Conclusion. Carambola wine treated with 0.3\% pectolase with the inclusion of $1 \%$ citric acid and $0.25 \%$ ascorbic acid with different yeast strains had (7.35 to 7.65$)^{\circ}$ Brix, (10.25 to 11.50 )\% alcohol, pH 3.01 to 3.02 , (79.20 to 88.55$) \%$ of light transmittance and (17.50 to 17.76$) \mathrm{mg}$ ascorbic acid $100 \mathrm{~mL}^{-1}$. These wines had overall acceptability rating from slightly to moderately liked and they were judged as superior.

Trinidad and Tobago / Averrboa carambola / processing / winemaking / fermentation / browning / organoleptic analysis / optical properties

\section{Effets de différentes concentrations de pectolase et de diverses souches de levure sur la qualité du vin de carambole à Trinidad, Antilles.}

Résumé - Introduction. Le fruit du carambolier (Averrhoa carambola L.), ou carambole, est un fruit tropical attrayant de la famille des oxalidacées. Comme la plupart de la production est consommée fraîche, très peu de caramboles sont transformées. Cependant, la qualité très variable du fruit produit dans la zone caraïbe limite fortement la pénétration du marché. Pour les caramboles de moins bonne qualité qui ne peuvent pas être commercialisées, la transformation des fruits pourrait permettre de limiter les pertes, d'améliorer les revenus du producteur et d'augmenter la valeur de la récolte. Nos travaux ont donc cherché à étudier la qualité du vin de carambole en relation avec certains traitements appliqués avant la fermentation du moût. Matériel et méthodes. De la pectolase a été ajoutée à de la pulpe pasteurisée de carambole aux concentrations de $(0,0,1,0,2$ et 0,3$) \%$. Un autre traitement a utilisé de la pectolase à $0,3 \%$ avec addition de $1 \%$ d'acide citrique et $0,25 \%$ d'acide ascorbique et associée à l'utilisation de différentes souches de levure de Saccharomyces cerevisiae provenant de différents vins (Super, Chablis et Sweet Mead). Le moût a été ajusté à $25^{\circ}$ Brix et à un pH de 3,03,5. La qualité du vin de carambole obtenu à l'issue de chacun des traitements a été évalué à l'aide de caractéristiques physico-chimiques et d'analyses organoleptiques. Résultats et discussion. L'addition de pectolase a amélioré la transmission de la lumière, la coloration, la clarté et l'acceptabilité globale du vin de carambole. L'addition d'acide citrique à $1 \%$ et d'acide ascorbique à $0,25 \%$ au moût a produit des vins moins foncés et moins jaunes, de couleur plus acceptable. Les vins fermentés avec des souches de levures de Chablis ont été les plus clairs (transmission de la lumière de 88,55 \%). Tous les vins ont été microbiologiquement stables. Conclusion. Le vin de carambole traité avec de la pectolase à $0,3 \%$ et addition d'acide citrique à $1 \%$ et ascorbique à $0,25 \%$, puis fermenté à partir de l'utilisation de différentes souches de levures, a été caractérisé par un brix de 7,35 à 7,65, un taux d'alcool de $(10,25$ à 11,50$) \%$, un pH de 3,01 à 3,02, un taux de transmission de la lumière de $(79,20$ à 88,55$) \%$ et $(17,50$ à 17,76$) \mathrm{mg}$ acide ascorbique $100 \mathrm{~mL}^{-1}$. Ce vin a été évalué comme légèrement à modérément apprécié et il a été considéré comme un vin supérieur.

Trinité-et-Tobago / Averrboa carambola / traitement / vinification / fermentation / brunissement / analyse organoleptique / propriété optique 


\section{Introduction}

The carambola (Averrboa carambola) is a member of the Oxalidaceae family [1] and is believed to have originated from Indonesia [2]. Unlike most tropical fruits that have one season, the carambola tree fruits twice and sometimes three times [3] or can yield three to five crops in a single year [4]. In Trinidad and Tobago, West Indies, the largest crop matures during May-June, September-October and December-January [5].

Carambolas are very desirable for their star-shaped slices, crispness and unique flavour, and the demand for carambola has increased in recent years [6]. They can be eaten as fresh fruit, dried fruit, juices, candied fruits and canned pulp [7]. The fruit provides flavor to stir-fried entrees, puddings, tarts, stews and curries [1]. The acceptability of the juice alone, and the juice mixed with other tropical fruit juices, has been investigated [8]. In its fresh state, the fruit is often disliked due to its sour and unpalatable taste [9].

Carambola fruits are easily bruised and thus care must be taken at harvesting to prevent injury [10]. Enzymatic browning has been noted as a quality issue in fruits and vegetables [11] and is a major problem in carambola. The browning susceptibility of cut or injured tissue has been mainly attributed to oxidation of phenolic compounds by enzymes, primarily polyphenol oxidase [12] and the phenolic concentration [13]. The phenoloxidase was isolated and characterized from carambola [14]. However, treating fresh carambola slices in a solution of $1 \%$ citric acid and $0.25 \%$ ascorbic acid can limit browning [13]. Cut carambolas subjected to high-pressure processing of $800 \mathrm{MPa}$ for 3 min maintained excellent color after being stored for 2 or 4 weeks at $3{ }^{\circ} \mathrm{C}$, then exposed to air for $8 \mathrm{~h} \mathrm{[6].} \mathrm{Approximately} 25 \%$ of carambola fruits, due to their size, shape and appearance, do not meet the desired market standards. The current emphasis is on the fresh fruit market and with very little processing. However, the high variability in fruit quality produced by Caribbean countries has been a major limitation to market penetration [10]. Processing of carambolas can allow the utilization of low quality fruits, which cannot be marketed, to reduce waste, improve on the economic returns of farmers and increase the value of the crop. Therefore, our objectives were to investigate the effect of pectolase concentration and wine yeast strains (Saccharomyces cerevisiae) on the physicochemical, microbial and sensory qualities of carambola wines and to study the effect of the incorporation of $1 \%$ citric and $0.25 \%$ ascorbic acid (antioxidant) on the quality of the wines.

\section{Materials and methods}

\subsection{Fermentation}

For the production of the carambola wine (figure 1), ripe carambolas of the 'ChenTsey' variety were obtained from Ambrosia Farm, Couva, Trinidad, West Indies. The fruits were washed and dipped in chlorinated water (200 $\mu$ g sodium hypochlorite $\left.\cdot \mathrm{mL}^{-1}\right)$ [13], diced and blended into a pulp using speed no. 3 for 3 min (Oster, model \# 889 16R, New Harford, Connecticut, USA). The fruit was pasteurized at $85^{\circ} \mathrm{C}$ for $10 \mathrm{~min}$.

In the first stage of the process, different concentrations $(0 \%, 0.1 \%, 0.2 \%$ or $0.3 \%)$ of pectolase enzyme (Young's Home Brew Ltd., Bilson, West Midlands WV 14BDL) were added to $12.5 \%$ of carambola pulp and allowed to incubate for $24 \mathrm{~h}$ at $20-22{ }^{\circ} \mathrm{C}$ prior to the addition of the yeast. Another treatment consisted of pulp with the addition of $0.3 \%$ pectolase, $1 \%$ citric acid and $0.25 \%$ ascorbic acid (v/v). Granulated sucrose was added to adjust the total soluble solids of the must from ( 5 to 25$)^{\circ}$ Brix and the $\mathrm{pH}$ from an initial 4.5 to $3.0-3.5$ with citric acid. Only Super wine yeast (Unican Company, Norwich, England), (Saccharomyces cerevisiae var. ellipsoideus) was diluted at $125 \mathrm{~mL} \cdot 13 \mathrm{~L}^{-1}$ $(\mathrm{v} / \mathrm{v})$ in fermentation along with $2.2 \%$ yeast nutrient (diammonium phosphate with ammonium phosphate).

In the second stage of the trials, the fruit content in the must was increased to $16.7 \%$ of pulp. The must was incubated with $0.3 \%$ pectolase, $1 \%$ citric acid and $0.25 \%$ ascorbic acid, and either the Super wine yeast, or Chablis or Mead Sweet (Vinter's choice, Wyeast, 
Mt. Hood, Oregon, USA) strains of yeast. The dilution rate was $35 \mathrm{~mL}$ yeast $13 \mathrm{~L}^{-1}$ wine $(\mathrm{v} / \mathrm{v})$. At the end of a primary fermentation for 7 days at $20-22{ }^{\circ} \mathrm{C}$, the wine was siphoned into sterilized demijohns to which air locks were fitted. A secondary fermentation was then carried out for 3 weeks at 20$22{ }^{\circ} \mathrm{C}$. To the siphoned wines, $100 \mathrm{~g}$ sodium metabisulphite $\cdot \mathrm{mL}^{-1}$ with $0.1 \%$ bentonite was added.

\subsection{Experimental design}

At the first stage, four treatments were applied corresponding to the levels of pectolase added to the carambola must: $0 \%$ $\left(\mathrm{T}_{1}\right), 0.1 \%\left(\mathrm{~T}_{2}\right), 0.2 \%\left(\mathrm{~T}_{3}\right)$ and $0.3 \%\left(\mathrm{~T}_{4}\right)$. In a fifth treatment $\left(\mathrm{T}_{5}\right), 1 \%$ citric acid with $0.25 \%$ ascorbic acid were added to $\mathrm{T}_{4}$ must $(0.3 \%$ pectolase $)$ which was selected due to its highest light transmittance $(78.10 \%$ at $p<0.05$ ) (table I). The experiment was replicated with the five treatments. Each replicate of the experiment was duplicated $(\sim 13 \mathrm{~L})$. The quality of the finished wines was analyzed 1 week after the final racking for physicochemical and microbiological quality.

At the second stage, based on instrumental color (figure 2) and sensory color (table II), $\mathrm{T}_{5}$ was chosen for further work. However, due to the low sensory scores for taste (3.64$4.50)$ and aroma (4.44-4.72) in the pectolase-treated wines (table II), the level of carambola pulp in the must was increased from $12.5 \%$ (stage 1 ) to $16.7 \%$ (stage 2). The experimental design comprised three treatments (Super wine yeast, Chablis wine yeast and Sweet Mead wine yeast) per two replicates. Each treatment was replicated. The physicochemical, microbiological and organoleptic qualities of the finished wines were conducted 1 week after the final racking of the wines.

\subsection{Physicochemical analysis}

The color of the fruit and wines was measured using a Minolta Chroma meter (model \# CR- 200 b, Minolta Camera Co Ltd., Ramsey, New Jersey). The Minolta colorimeter was standardized with a white tile $(\mathrm{L}=92.6$, $a=0.3137$ and $b=0.3209)$ and the $L, a$ and

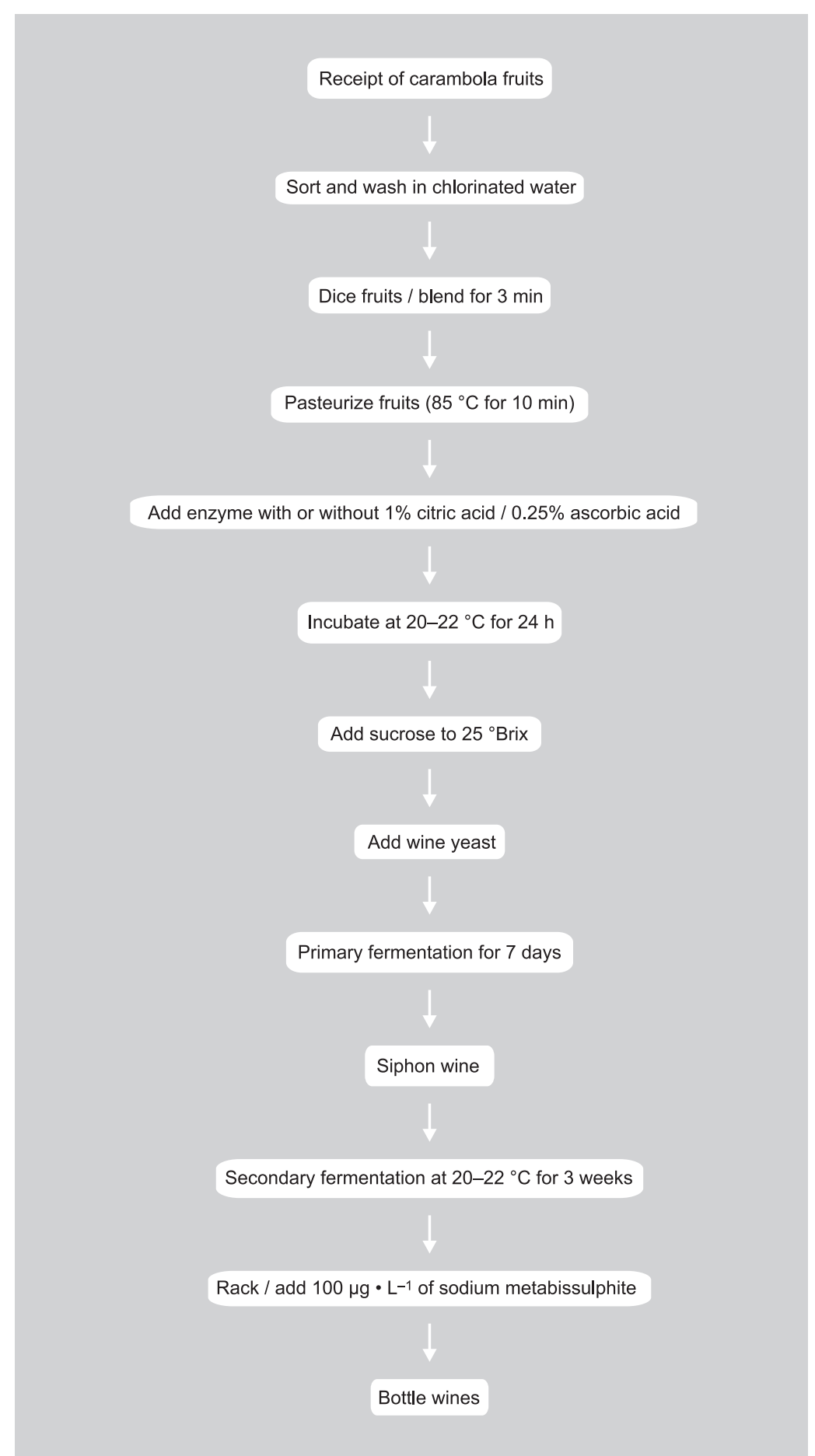

$b$ values were taken for each wine. The $L$ value represented lightness of color (the higher the value, the lighter the color), $a$ was negative for green and positive for red, and $b$

\section{Figure 1.}

Flow chart of stages for carambola wine production in Trinidad (West Indies). 


\section{Table I.}

Changes in physicochemical charateristics of carambola wines obtained from fermentation of must with the addition of varying pectolase concentrations and yeast strains.

(a) Primary fermentation with Super wine yeast (Unican Company, Norwich, England), (Saccharomyces cerevisiae var. ellipsoideus)

\begin{tabular}{|c|c|c|c|c|c|c|c|c|}
\hline \multicolumn{3}{|c|}{ Treatment for primary wine fermentation } & \multicolumn{6}{|c|}{ Physicochemical characteristics } \\
\hline Notation & $\begin{array}{l}\text { Pectolase } \\
\text { (\%) }\end{array}$ & Additional element & $\begin{array}{l}\text { TSS } \\
\left({ }^{\circ} \text { Brix }\right)\end{array}$ & $\begin{array}{l}\text { Alcohol } \\
(\%)\end{array}$ & $\mathrm{pH}$ & $\begin{array}{l}\text { Titratable acidity } \\
\text { (\% citric acid })\end{array}$ & $\begin{array}{l}\text { Light transmittance } \\
\text { (\%) }\end{array}$ & $\begin{array}{l}\text { Ascorbic acid } \\
\left(\mathrm{mg} \cdot 100 \mathrm{~mL}^{-1}\right)\end{array}$ \\
\hline $\mathrm{T}_{1}$ & 0 & - & $6.35 \mathrm{a}$ & $9.25 a$ & $3.03 \mathrm{a}$ & $0.041 \mathrm{~b}$ & $20.75^{d}$ & $1.26 \mathrm{~b}$ \\
\hline $\mathrm{T}_{2}$ & 0.1 & - & $6.40 \mathrm{a}$ & $9.25 \mathrm{a}$ & $3.06 \mathrm{a}$ & $0.041 \mathrm{~b}$ & $65.60 \mathrm{~b}$ & $1.26 \mathrm{~b}$ \\
\hline $\mathrm{T}_{3}$ & 0.2 & - & $6.65 \mathrm{a}$ & $9.25 \mathrm{a}$ & $3.06 \mathrm{a}$ & $0.043 \mathrm{~b}$ & $69.85 \mathrm{c}$ & $1.27 \mathrm{~b}$ \\
\hline $\mathrm{T}_{4}$ & 0.3 & - & $6.70 \mathrm{a}$ & $9.15 \mathrm{a}$ & $3.01 \mathrm{a}$ & $0.044 \mathrm{~b}$ & $78.10 \mathrm{a}$ & $1.27 \mathrm{~b}$ \\
\hline $\mathrm{T}_{5}$ & 0.3 & $\begin{array}{c}1 \% \text { citric acid } \\
+0.25 \% \text { ascorbic acid }\end{array}$ & $7.15 \mathrm{a}$ & $9.10 \mathrm{a}$ & $3.05 \mathrm{a}$ & $0.098 \mathrm{a}$ & $81.05 \mathrm{a}$ & $18.60 \mathrm{a}$ \\
\hline
\end{tabular}

(b) Secondary fermentation with different yeast strains carried out only with the $T_{5}$ treatment $(0.3 \%$ pectolase $+1 \%$ citric acid + $0.25 \%$ ascorbic acid)

\begin{tabular}{|c|c|c|c|c|c|c|}
\hline \multirow[t]{2}{*}{ Wine yeast strain added } & \multicolumn{6}{|c|}{ Physicochemical characteristics } \\
\hline & $\begin{array}{l}\text { TSS } \\
\text { ('Brix) }\end{array}$ & $\begin{array}{l}\text { Alcohol } \\
(\%)\end{array}$ & $\mathrm{pH}$ & $\begin{array}{l}\text { Titratable acidity } \\
\text { (\% citric acid) }\end{array}$ & $\begin{array}{l}\text { Light transmittance } \\
\text { (\%) }\end{array}$ & $\begin{array}{l}\text { Ascorbic acid } \\
\left(\mathrm{mg} \cdot 100 \mathrm{~mL}^{-1}\right)\end{array}$ \\
\hline Super wine & $7.35 \mathrm{~b}$ & $10.25 \mathrm{~b}$ & $3.11 \mathrm{a}$ & $0.093 a$ & $79.20 \mathrm{c}$ & $17.50 \mathrm{a}$ \\
\hline Chablis & $7.55 \mathrm{a}$ & $11.25 \mathrm{a}$ & $3.12 \mathrm{a}$ & $0.091 \mathrm{a}$ & $88.55 \mathrm{a}$ & $17.76 \mathrm{a}$ \\
\hline Sweet Mead & $7.65 a$ & $11.50 \mathrm{a}$ & $3.09 a$ & $0.082 \mathrm{~b}$ & $84.55 \mathrm{~b}$ & $17.50 \mathrm{a}$ \\
\hline
\end{tabular}

was negative for blue and positive for yellow [15]

The alcohol content was determined by the refractive index of the distillate using an immersion refractor (ABBE - 60, Bellingham and Stanley, Kent, England) as outlined by \# 920.58 [16].

Total soluble solids (TSS) as ${ }^{\circ}$ Brix was determined on the fresh carambola, must and wines using a refractometer (Leica Model, Atago E Type Seires, Leica Inc., Buffalo, NY) [17].

Clarity as percentage light transmission was measured using a spectrophotometer (model Co 99-0993, Lambda, 3B dual beam UV/VIS, Perkins-Elmer Inc., Altamara, San Juan, Puerto Rico) [18]. The reading was taken at $425 \mathrm{~nm}$.

Ascorbic acid content of the fresh fruit and wines was determined using the 2,6dichloroindophenol titrimetric method as out- lined by \# 967.21 [16]. The pH of the must and wines was measured using an Orion $\mathrm{pH}$ meter (Model 520A, Orion Research Inc., Beverly, MA) which was calibrated with a buffer solution 7.41. Total titratable acidity (TAA) was expressed as \% citric acid and was determined by titration using $1 \mathrm{~N} \mathrm{NaOH}$ and phenolphthalein as outlined by \# 962.12 [16].

\subsection{Microbiological analysis}

Total plate count, yeast and molds, and lactic acid bacteria were enumerated using serial dilutions of the wines followed by the pour plate technique. Plate Count Agar (PCA, Difco, Detroit, MI), Tomato Juice Agar (TJA, Difco, Detroit MI) and Potato Dextrose Agar (PDA, Difco, Detroit, MI) were used in the enumeration of total aerobic mesophiles, lactic acid bacteria and yeast and molds. PCA plates were incubated at $35^{\circ} \mathrm{C}$ 
for $48 \mathrm{~h}$, TJA plates and PDA plates at $28{ }^{\circ} \mathrm{C}$ for $24 \mathrm{~h}$ [19]. The number of microorganisms was recorded as $\mathrm{cfu} \cdot \mathrm{mL}^{-1}$.

\subsection{Sensory analysis}

Sensory evaluation was conducted in an odor-free individual booth which was lit by fluorescent lighting at the Food Biology Laboratory, University of the West Indies, St. Augustine, Trinidad, West Indies. Initial assessor selection criteria were based on personal interest and availability. Fifty untrained panelists who are consumers of fruit wines were selected for sensory evaluation of the wines. Hedonic testing was performed in different sessions on wines from the first stage of the experiment $\left(\mathrm{T}_{1}, \mathrm{~T} 2, \mathrm{~T}_{3}, \mathrm{~T}_{4}\right.$ and T5) and on wines treated with different yeast strains (Super, Sweet Mead and Chablis) from the second stage of fermentation. The order of presentation of wines to the panelists was randomized. All samples $(30 \mathrm{~mL})$

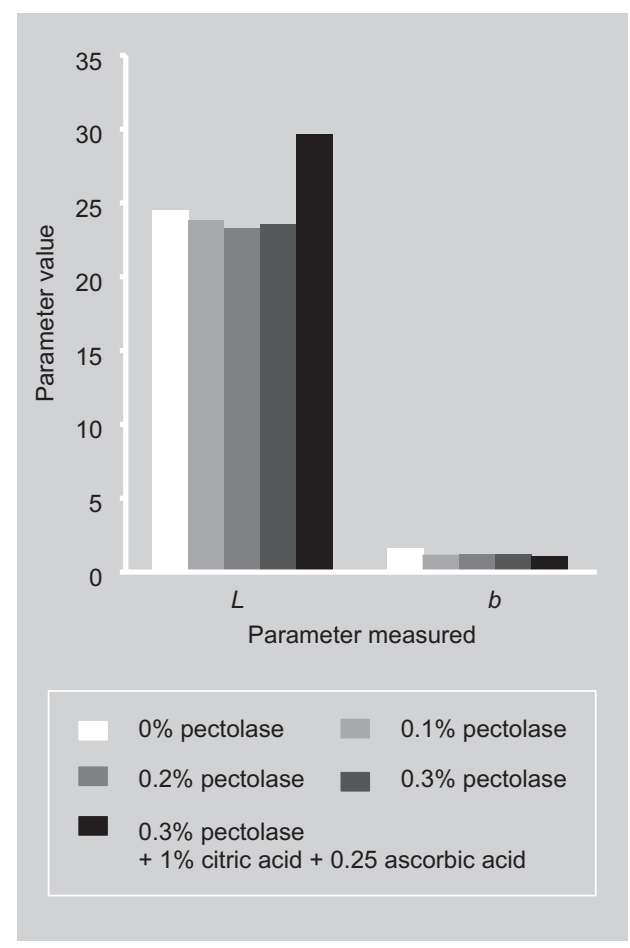

Figure 2

Effect of different concentrations of pectolase added to carambola must on color (LSD: $L=0.932$, $b=0.073)$ of carambola wines obtained after fermentation (Trinidad, West Indies).

\section{Table II.}

Changes in sensory scores of carambola wines obtained from fermentation of must with the addition of varying pectolase concentrations and yeast strains due to enzyme concentration and yeast strain. (Scale used to assess scores: 9 - liked extremely, 8 - liked very much, 7 - liked moderately, 6 - liked slightly, 5 - neither liked nor disliked, 4 - disliked slightly, 3 - disliked moderately, 2 - disliked very much, 1 - disliked extremely.)

(a) Primary fermentation with Super wine yeast (Unican Company, Norwich, England), (Saccharomyces cerevisiae var. ellipsoideus)

\begin{tabular}{|c|c|c|c|c|c|c|c|}
\hline \multicolumn{3}{|c|}{ Treatment for primary wine fermentation } & \multicolumn{5}{|c|}{ Sensory characteristics } \\
\hline Notation & $\begin{array}{l}\text { Pectolase } \\
\text { (\%) }\end{array}$ & Additional element & Color & Clarity & Aroma & Taste & Overall acceptability \\
\hline $\mathrm{T}_{1}$ & 0 & - & $3.88 \mathrm{c}$ & $2.74 \mathrm{~b}$ & $3.98 \mathrm{a}$ & $2.80 \mathrm{a}$ & $3.37 \mathrm{c}$ \\
\hline $\mathrm{T}_{2}$ & 0.1 & - & $6.84 \mathrm{~b}$ & $6.98 \mathrm{a}$ & $4.56 \mathrm{a}$ & $4.06 \mathrm{a}$ & $5.63 \mathrm{~b}$ \\
\hline $\mathrm{T}_{3}$ & 0.2 & - & $6.90 \mathrm{~b}$ & $6.88 \mathrm{a}$ & $4.72 \mathrm{a}$ & $4.50 \mathrm{a}$ & $5.75 a$ \\
\hline $\mathrm{T}_{4}$ & 0.3 & - & $7.15 \mathrm{~b}$ & $7.10 \mathrm{a}$ & $4.45 \mathrm{a}$ & $4.00 \mathrm{a}$ & $5 . .70 \mathrm{a}$ \\
\hline $\mathrm{T}_{5}$ & 0.3 & $\begin{array}{c}1 \% \text { citric acid } \\
+0.25 \% \text { ascorbic acid }\end{array}$ & $7.56 \mathrm{a}$ & $7.50 \mathrm{a}$ & $4.44 \mathrm{a}$ & $3.64 \mathrm{a}$ & $5.79 \mathrm{a}$ \\
\hline
\end{tabular}

(b) Secondary fermentation with different yeast strains carried out only with the $\mathrm{T}_{5}$ treatment $(0.3 \%$ pectolase $+1 \%$ citric acid + $0.25 \%$ ascorbic acid)

\begin{tabular}{lccccc} 
Wine yeast strain added & \multicolumn{3}{c}{ Sensory characteristics } \\
& Color & Clarity & Aroma & Taste & Overall acceptability \\
Super wine & $6.46 \mathrm{~b}$ & $6.56 \mathrm{~b}$ & $6.84 \mathrm{a}$ & $6.92 \mathrm{a}$ & $6.70 \mathrm{a}$ \\
Chablis & $6.80 \mathrm{a}$ & $6.74 \mathrm{a}$ & $6.66 \mathrm{a}$ & $6.22 \mathrm{a}$ & $6.61 \mathrm{a}$ \\
Sweet Mead & $6.14 \mathrm{a}$ & $5.84 \mathrm{~b}$ & $6.50 \mathrm{a}$ & $6.76 \mathrm{a}$ & $6.31 \mathrm{~b}$
\end{tabular}

Means followed by the same letter in a column do not differ by a Least Significance Difference analysis $(p>0.05)$. 
Table III.

Attributes used by the panelists for judging the quality of carambola wines (Trinidad and Tobago, West Indies).

\begin{tabular}{|c|c|c|c|c|c|c|c|c|c|c|c|}
\hline Score & Appearance & Color & Odor & Flavor & Acidity & Bitterness & Sweetness & Vinegary & Clarity & Body & $\begin{array}{l}\text { General } \\
\text { quality }\end{array}$ \\
\hline 0 & Cloudy & $\begin{array}{c}\text { Distinctly } \\
\text { off }\end{array}$ & $\begin{array}{c}\text { Completely } \\
\text { off }\end{array}$ & - & $\begin{array}{l}\text { Distinctly } \\
\text { high or low }\end{array}$ & $\begin{array}{l}\text { Distinctly } \\
\text { high }\end{array}$ & $\begin{array}{l}\text { Too high } \\
\text { or low }\end{array}$ & Obvious & Lacking & $\begin{array}{l}\text { Too high } \\
\text { or low }\end{array}$ & Lacking \\
\hline 1 & Clear & $\begin{array}{l}\text { Slightly } \\
\text { off }\end{array}$ & $\begin{array}{l}\text { Slightly } \\
\text { off }\end{array}$ & $\begin{array}{l}\text { Distinctly } \\
\text { abnormal }\end{array}$ & $\begin{array}{l}\text { Slightly high } \\
\text { or low }\end{array}$ & $\begin{array}{l}\text { Slightly } \\
\text { high }\end{array}$ & Normal & Slight & Slight & Normal & Slight \\
\hline 2 & Brilliant & Correct & Impressive & Normal & Normal & Normal & - & None & Impressive & - & Impressive \\
\hline
\end{tabular}

were coded and served chilled $\left(18-20^{\circ} \mathrm{C}\right)$. The temperature of the wines was important as the taste of tannins is less obvious at a low temperature [20].

The sensory quality tests were conducted on wines treated with different yeasts by twelve experienced panelists. These panelists could be considered as wine connoisseurs, because of their general knowledge of, interest in and experience of wines and participation in previous sensory evaluations. The panelists were subjected to two 3-h training sessions to become familiar with the sensory attributes of the wines. During training, each panelist was introduced to the score card and the procedures of sensory evaluation. A commercial grape wine was used as a reference wine to assist in the identification of the common quality attributes and representation of 'low' and 'high' intensity of the terms. The panelists were asked to do replications to be able to demonstrate the reliability of the data. A modified version of the 20-point rating system was used [21]. The quality attributes of the wines were judged by qualitative notes (table III). Wines were judged as being superior: $17-20$, standard: 13-16, below standard: 9-12, or unacceptable or spoiled: 1-8.

\subsection{Statistical analysis}

The data from the physicochemical analyses and sensory evaluation were subjected to analysis of variance using Minitab Statistical Software 12 for Windows (Minitab, 1991, Enterprise State College PA 16801-3008) to investigate the effects of pectolase concentration and wine yeast strains on the quality of the wines. When there was a significant F-value $(p<0.05)$, the means were separated by a Least Significance Difference analysis. The quality rating scores from the wine quality evaluation were analyzed using the Kruskal-Wallis test at $p<0.05$.

\section{Results and discussion}

\subsection{Physicochemical quality}

\subsubsection{Pectolase treatments}

The addition of pectolase to the must $\left(\mathrm{T}_{1}\right.$, $\mathrm{T}_{2}, \mathrm{~T}_{3}$ and $\mathrm{T}_{4}$ ) had no effect on the wine's total soluble solids (TSS), \% alcohol, pH, titratable acidity as \% citric acid, and ascorbic acid (table 1 ). Only the $\%$ light transmittance, which was the highest (78.10\%) for the treatment with $0.3 \%$ of pectolase, showed an effect. The TSS of the must dropped from an initial $25^{\circ}$ Brix to 6.35$6.70^{\circ} \mathrm{Brix}$ in the carambola wines, while the alcohol content varied between $(9.10$ and $9.25) \%$. The fruit $\mathrm{pH}$ was $2.88-3.01$ and $\mathrm{pH}$ varied from 3.01 to 3.06 for the enzymetreated wines.

As expected, wine from the treatment $\mathrm{T}_{5}$ (with addition of $1 \%$ citric acid and $0.25 \%$ ascorbic acid) had the highest level of citric acid and ascorbic acid among the wines. That wine had $18.60 \mathrm{mg}$ ascorbic acid $100 \mathrm{~mL}^{-1}$, compared with the other wines, which had (12.6-12.7) $\mathrm{mg}$ ascorbic acid $100 \mathrm{~mL}^{-1}$. Oxalic acid is the principal acid found in carambola, but other acids are present, including fumaric, citric, malic, $\alpha$-ketoglutaric, succinic and tartaric acid [22]. The total organic 
acid content of the mature green fruit was $1.25 \mathrm{~g} \cdot 100 \mathrm{~g}^{-1}$ fresh fruit and that of the ripe fruit rose to $1.3 \mathrm{~g} \cdot 100 \mathrm{~g}^{-1}$ fresh fruit [22]. The 'sweet' type of carambola is mildflavored and has less oxalic acid than the 'sour' type which is richly flavored [4]. The ascorbic acid content of the fruit was reported to be $35.00 \mathrm{mg} \cdot 100 \mathrm{~g}^{-1}$ [4] and (26.0 to 53) $\mathrm{mg} \cdot 100 \mathrm{~g}^{-1}$ [1]. Our results indicate that the fresh fruit contained (36.0 to 37.0$) \mathrm{mg}$ ascorbic acid. $100 \mathrm{~g}^{-1}$.

Wine clarity was highest in wines $\left(\mathrm{T}_{4}, \mathrm{~T}_{5}\right)$ with $0.3 \%$ pectolase (78.10-81.05\% light transmittance, respectively). Compared with control $\left(\mathrm{T}_{0}\right)$ wine with $20.75 \%$ light transmittance, the addition of an increasing level of pectolase resulted in the improvement in $\%$ light transmittance of the wines. Wines prepared from grapes treated with pectic enzymes clarify more rapidly and produce more total juice or wine than untreated grapes [23].

\subsubsection{Yeast strains}

The use of different yeast strains resulted in variations in alcohol content, with higher content for Chablis and Sweet Mead yeast strains as compared with Super Yeast (table I). According to a classification of the Caribbean Industrial Research Institute (Trinidad), the carambola wines could be categorized as table wines since their alcohol contents range from 9-12\% (v/v) [24]. The sweet type of the carambola rarely has more than $4 \%$ sugar [1]. Wills et al. reported that sucrose was the predominant sugar in that fruit [25]. However, Chan and Hue reported that glucose was the predominant sugar (51.0\%) in carambola followed by fructose (35.9\%) and sucrose (13.14\%) [26]. The total soluble sugar comprised mainly glucose and fructose [27]. The experimental carambola fruit (Chen Tsey variety) had (5.0 to 6.12) ${ }^{\circ}$ Brix.

The Chablis yeast-treated wine had the highest clarity (88.55\% light transmittance) among the wines. This type of yeast is highly flocculant and is recommended to be used for clear beverages without filtration (Wyeast Laboratories, Mt. Hood Oregon).

\subsection{Color}

Wine obtained after the $\mathrm{T}_{5}$ treatment $(0.3 \%$ pectolase with $1 \%$ citric acid and $0.25 \%$ ascorbic acid) was the brightest $(L=29.62)$ and least yellow (lowest $b=1.05$ ) of the wines (figure 2). The enzymes may have hydrolyzed the carotenoid pigments found in the fruit. The $b$ values of the fruit were 1.45-1.73 while those of the wines were $1.05-1.58$. The $a$ values $(-0.13$ to -0.29$)$ of the wines did not vary due to changes in pectolase levels. Appropriate additions of ascorbic acid can aid in minimizing persistent browning due to oxidation [28].

At the end of fermentation, the wine obtained from pulp treated with Chablis yeast was the least dark compared with the pulp with Super and Sweet Mead yeasts (figure 3). Wine from Sweet Mead yeast was the only wine with positive $a$ values (0.38) compared with those from Super yeast $(-1.06)$ and Chablis yeast $(-1.15)$. At the end of fermentation, the wine from Chablis yeast was the least yellow $(b=1.37)$, while the wine from the Super yeast was the yellowest $(b=$ 1.58).

\subsection{Sensory quality}

Wine without pectolase $\left(\mathrm{T}_{0}\right)$ had the lowest scores $(p<0.05)$ for sensory color, clarity

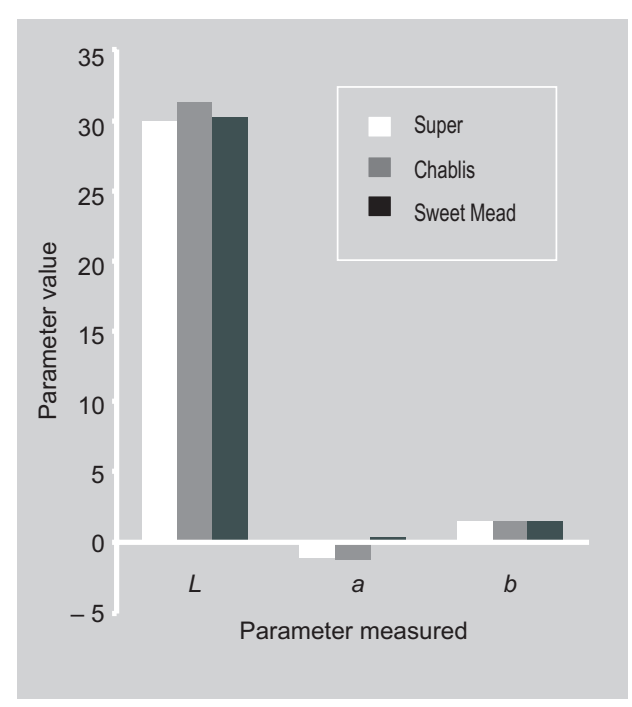

Figure 3.

Effect of different wine yeasts added to carambola must on color (LSD: $L=1.03, a=0.239$, $b=0.045$ ) of carambola wines. 
and overall acceptability compared with the other enzyme-treated wines (table II). The color of $\mathrm{T}_{5}$ wine was given the highest overall acceptability score 7.56 , being liked moderately to very much. Generally, among the sensory parameters used, taste (3.64 to 4.50) and aroma ( 4.44 to 4.72 ), the lowest scores were given for enzyme-treated wines. From the comments given by the panelists, sweeter and fruitier wines were desired.

According to our results (table I), the TSS of wines treated in the second stage with different yeast strains $\left[(7.35 \text { to } 7.65)^{\circ}\right.$ Brix] was higher than the TSS of enzyme-treated wines in the first stage [(6.35 to 7.15$\left.)^{\circ} \mathrm{Brix}\right]$. Thus, all the wines of the second stage were given good hedonic scores (6 to 7) for all attributes, except for clarity for wine from Sweet Mead yeast (5. 84). That yeast strain produces wine with fruity aromatic properties, while the Chablis yeast strain produces wine with floral fruity estery vanilla notes (Wyeast Laboratories, Mt. Hood Oregon, USA). All the wines obtained with the different yeasts had an overall acceptability of liked slightly to moderately (6.31 to 6.70).

Quality is a composite response to the sensory properties of wines based on one's expectations for a given wine type which are a function of one's previous experience with wines [29]. Wines were judged as being superior in quality and were given ratings of [(17.0 to 18.0) out of 20]. The carambola wines obtained had outstanding quality attributes such as brilliance in clarity with distinct fruity odor and taste, with no marked defects such as being abnormally sweet or vinegary.

\subsection{Microbiological quality}

All the carambola wines obtained had less than $10 \mathrm{cfu} \cdot \mathrm{mL}^{-1}$ of total aerobes, yeast and molds and lactic acid bacteria, and thus were microbiologically stable.

\section{Conclusions}

Carambola must treated with $0.3 \%$ pectolase, $1.0 \%$ citric acid and $0.25 \%$ ascorbic acid resulted in the least dark and yellow wine. Increasing the pectolase concentration and use of Chablis yeast improved the clarity of the wines. Wines liked slightly to moderately were judged as superior quality wines. They could be used as table wines with (10.25 to $11.50) \%$ alcohol, $\mathrm{pH} 3.01$ to 3.03, and total soluble solids of (7.35 to 7.65$)^{\circ}$ Brix.

\section{Acknowledgments}

We thank the Caribbean University level Program / European Union for providing funding, and Mr. Keshwar John, the late Mr. Shan Ali and Mr. Esau Mohammed for their technical assistance.

\section{References}

[1] Morton J., Fruits of warm climates. Media incorporated, Greensboro, North Carolina, USA, 1987.

[2] Barbeau G., Inventory of tropical fruit trees in Central America and the West Indies, Fruits 49 (1994) 383-389.

[3] Knight R.J., Strange fruits of the world, Miami Newsletter 20 (1986) 58.

[4] Ploetz R., Benscher D., Dorey A., Vásquez A., The epidemiology control and cause of sooty blotch of carambola, Averrhoa carambola L., in South Africa, Fruits 55 (2000) 241252.

[5] Andrews L., Ragoonath J., Carambola and bilimbi, Fruits 45 (1990) 497-501.

[6] Boynton B.B., Sims C.A., Sargent S., Balaban M.O., Quality and stability of precut mangos and carambolas subjected to high-pressure processing, J. Food Sci. 67 (1) (2002) 409415.

[7] Berry R.E., Wagner C.J., Shaw P.E., Knight R.J., Promising products from tropical fruits, Food Prod. Dev. 11 (1977) 109-112.

[8] Matthews R., Processing of carambola, Proc. Interam. Soc. Trop. Hortic. 33 (1989) 83.

[9] Andrews L., Prospects for carambola production in Trinidad and Tobago, Proc. InterAm. Soc. Trop. Hortic. 33 (1989) 12-89. 
[10] Campbell C.W., Marte R.J., Pre-production and post-harvest handling of carambola, Inter-American Inst. Coop. Agric., Bridgetown, Barbados, West Indies, 1990.

[11] Shewfelt A.l., Flavor and color of fruits as affected by processing, in: Woodroof J.G., Luh B.S., Commercial fruit processing, AVI Publ. Co., Westport, USA, 1975, pp. 497-531.

[12] Vamos-Vigyazo L., Polyphenol oxidase and peroxidase in fruits and vegetables, Crit. Rev. Food Sci. 15 (1981) 49-127.

[13] Weller A., Sims C., Matthews R., Bates R., Brecht J., Browning susceptibility and changes in composition during storage of carambola slices, J. Food Sci. 62 (1997) 256-260.

[14] Adnan T., Augutin M.A., Ghazali H.M., Polyphenoloxidase from starfruit (Averrhoa carambola L.), Pertanika 9 (1986) 219-224.

[15] Francis F.J., Colour analysis, in: Nielsen S.S. (Ed.), Food Analysis, Aspen Publ., Unc., Gaithersburg, USA, 1998, pp. 601-611.

[16] Anonymous, Official methods of analysis, 15th ed., AOAC, Blackie Acad. Prof., London, UK, 1990.

[17] Bradley R.L., Moisture and total solids analysis, in: Nielsen S. (Ed.), Aspen Publ., Gaithersburg, USA, 1998, pp. 133-135.

[18] Vine R.P., Commercial wine making - Processing and control, AVI Publ. Co., Westport, USA, 1981, pp. 185-187.

[19] Benson HJ., Microbiological applications: a laboratory manual in general microbiology, Browne Wm.C., Dubuque, lowa, USA, 1985.
[20] Meilgaard M., Vance G., Carr B.T., Sensory evaluation techniques, CRC Press Inc., Florida, USA, 1991, pp. 34-39.

[21] Lawless H., Heymann H., Sensory evaluation of food: principles and practices, Chapman and Hall, New York, USA, 1998.

[22] Vines H.M., Grierson W., Handling and physiological studies with the carambola, Proc. Fla. State Hortic. Soc. 79 (1966) 350-355.

[23] Neubeck C.E., Fruits, fruit products and wines, in: Reed G. (Ed.), Enzymes in food Processing, Acad. Press, New York, USA, 1975, pp. 397-441.

[24] Anonymous, Basic principles of fruit wine production, Caribb. Ind. Res. Inst. (CARIRI), Trinidad, West Indies, 1992.

[25] Wills R.B., Lim J.S.K., Greenfield H., Composition of Australian foods. Tropical and Sub-tropical fruits, Food Tech. Australia 38 (1986) 118-123.

[26] Chan H.T. Jr., Hue R.A., identification and determination of sugars in starfruit, sweetsop, green sapote, jackfruit and West Indian apple, J. Food Sci. 40 (1975) 1329-1330.

[27] Campbell C.A., Koch K.E., Sugar/acid composition and development of sweet and tart carambola fruit, J. Am. Soc. Hortic. Sci. 114 (1989) 455-457.

[28] Panagiotakopoulou V., Morris J.R., Chemical additives to reduce browning in white wines, Am. J. Enol. Viticult. 42 (1991) 255-260.

[29] Noble A.C., Analysis of wine sensory properties, in: Linskens H.F., Jackson J.F., Wine analysis, Springer-Verlag, New York, USA, 1988, pp. 9-28. 


\section{Efectos de diferentes concentraciones de pectolasa y de distintas cepas de levadura en la calidad del vino de carambola en Trinidad, Antillas.}

Resumen - Introducción. La carambola (Averrboa carambola L.) es un árbol frutal de la familia de las oxalidáceas que produce vistosos frutos llamados carambolas o frutas estrella. Como la mayoría de la producción se consume fresca, se transforman muy pocas carambolas. Sin embargo, la calidad muy irregular de la fruta producida en la zona del Caribe limita mucho la penetración del mercado. La transformación de las carambolas de inferior calidad, que no pueden comercializarse, podría permitir limitar las pérdidas, mejorar los ingresos del productor y aumentar el valor de la cosecha. Nuestro trabajo tenía como objetivo estudiar la calidad del vino de carambola con relación a algunos tratamientos aplicados antes de la fermentación del mosto. Material y métodos. Se añadió pectolasa a la pulpa pasteurizada de carambola con concentraciones de $(0,0,1,0,2$ y 0,3$) \%$. Otro tratamiento utilizó pectolasa al $0,3 \%$ añadiendo $1 \%$ de ácido cítrico y $0,25 \%$ de ácido ascórbico y asociándola a la utilización de diferentes cepas de levadura de Saccharomyces cerevisiae procedentes de distintos vinos (Super, Chablis y Sweet Mead). El mosto se ajustó a $25^{\circ}$ Brix y a un pH de 3,0-3,5. Se evaluó la calidad del vino de carambola obtenido después de cada uno de los tratamientos mediante características fisicoquímicas y análisis organolépticos. Resultados y discusión. La adición de pectolasa mejoró la transmisión de la luz, la coloración, la claridad y la aceptabilidad global del vino de carambola. La adición de ácido cítrico al 1\% y de ácido ascórbico al 0,25\% al mosto produjo vinos menos oscuros y menos amarillos, de color más aceptable. Los vinos fermentados con cepas de levaduras de Chablis fueron los más claros (transmisión de la luz del 88,55\%). Todos los vinos eran microbiológicamente estables. Conclusión. El vino de carambola tratado con pectolasa al $0.3 \%$ y adición de ácido cítrico al 1\% y ascórbico al $0.25 \%$ y, luego, fermentado a partir de la utilización de distintas cepas de levaduras, se caracterizó por un brix de 7,35 a 7,65 , un porcentaje de alcohol del $(10,25$ al 11,50)\%, un pH de 3,01 a 3,02 , un porcentaje de transmisión de la luz del $(79,20$ al 88.55$) \%$ y (17.50 a 17.76) $\mathrm{mg}$ de ácido ascórbico $100 \mathrm{~mL}^{-1}$. En cata, este vino tuvo una apreciación entre ligera a moderada y se consideró como un vino superior.

Trinidad y Tobago / Averrboa carambola / procesamiento / vinificación / fermentación / oscurecimiento / análisis organoléptico / propiedades ópticas

To access this journal online: www.edpsciences.org 